\title{
The Typology of Digital Entrepreneurship in Morocco
}

\author{
Anaflouss Nadia* and Jamal Youssef \\ Economic and Social Sciences of Mohammedia, The Research Laboratory of Entrepreneurship and \\ Environmental Management of the Company, Morocco; nadia.anaflouss@gmail.com, \\ prof.youssefjamal@gmail.com
}

\begin{abstract}
Objectives: This article aims to establish a critical presentation of the typology of digital entrepreneurship in Morocco. It proposes to characterize the typology from which entrepreneurs' thoughts about starting a new digital adventure are formed. Methods/Statistical Analysis: A qualitative study was conducted with a panel of Moroccan digital entrepreneurs to understand the typology of digital entrepreneurship in Morocco. Findings: The results obtained highlight two major results. First, we found the presence of a form of homogeneity of digital entrepreneurs' beliefs. Next, we noticed the existence of 2 forms of digital entrepreneurship: Moderate \& Extreme. Application/Improvements: The article incorporates a series of discussion to understand the typology of digital entrepreneurship in Morocco, its particularities and also its benefits.
\end{abstract}

Keywords: Digital Benefits, Digital Entrepreneurship, Digital Particularities, Entrepreneurship, Typologies

\section{Introduction}

With the development of information and communication technologies (ICT), several companies have oriented their development strategies towards digitalization and have opted for a new business model which is totally different from the usual one ${ }^{1}$. The rapid pace of digital transformation has thus disrupted competitive environments and traditional business processes. Infact, digital has created a new form of entrepreneurship called digital entrepreneurship that "encompasses all new businesses and the transformation of existing businesses that generate economic and / or social value by creating and using new digital technologies"2. Digital businesses are characterized by intensive use of new digital technologies (especially social, Big data, mobile and cloud-based solutions) to improve business operations, invent new business models, strengthen business intelligence and engage with customers and stakeholders. They create the jobs and growth opportunities of the future ${ }^{3}$. Nowadays, companies have at their disposal several technologies that can use (social networks, big data and cloud solutions) to create, develop or promote their products and services ${ }^{4}$.
Just like traditional structures, goal of any digital company is to make a financial gain ${ }^{5}$. Indeed, the product if it is a good or a service (its place of work, its ease of entry on the market,its facility of manufacture or storage ...) are all the elements which make the difference between a traditional and a digital company ${ }^{\underline{6}}$. Entrepreneurs who intend to engage in digital must understand these differences as well as the opportunities arising from digital. $\operatorname{In}^{\mathrm{z}}$ the literature, researchers ${ }^{8}$ have tried to propose a framework of digital entrepreneurship where they show the typology of digital companies and their characteristics. We will therefore rely on this framework to understand the typology of digital entrepreneurship in Morocco.

\section{Digital Entrepreneurship}

Digital entrepreneurship is "a subcategory of entrepreneurship in which some or all of the physical components of an organization have been digitized"' Therefore, by definition, the products, distribution, workplace and all the physical elements that make up an organization could take the digital format ${ }^{*}$. Digital entrepreneurship refers to a new form of entrepreneurship

${ }^{*}$ Author for correspondence 
where entrepreneurial activity takes place in digital form rather than in a traditional form?

Like traditional structures, the ultimate goal of any digital one is to make a financial profit. The difference between these two forms of entrepreneurship relies in their business models, as well as the way in which entrepreneurs manage their products, marketing strategies and online distribution ${ }^{-}$.

\section{The Benefits of Digital Entrepreneurship}

Among the greatest advantages of digital entrepreneurship, the ease of entry into the market with the presence of barriers to entry less solid than those present in the form of traditional entrepreneurship?. Thus, it represents a very attractive option for all socially marginalized or economically disadvantaged actors to generate income from their entrepreneurial activity ${ }^{10}$.

\subsection{Ease of Entry on the Market}

With the development of ICTs, little time is needed to create a commercial website ${ }^{9}$. The emergence of web 2.0 is a tool that allows digital entrepreneurs to develop their activities and reach a community on the web that will be more or less likely to buy their products.

\subsection{Ease of Manufacture and Storage:}

On digital, the entrepreneur can opt for the marketing strategy (for goods \& services) which is completely digital or traditional; This choice will significantly impact its costs. Unlike traditional products, promoting a digital product on a digital platform doesn't generate any cost of manufacturing or storage. However, digital products require a complex creative process, but once the product is ready to be offered,no physical installation is needed to store it. So, digital entrepreneurship reduces many costs related to the traditional production process of products.

\subsection{Easy Distribution}

With the emergence of ICTs, customers today find themselves with a huge assortment of products and services offered to those customers wishing to order online. The delivery of digital products like (software, music, movies, ...) is immediate after making the payment. For other products such as online services (domain name purchase, article of clothing ...), delivery may take à few days. On the digital side, companies have to face the increased competition. And this, by setting up a customer service available $24 / 24$ and $7 / 7$ to respond to requests received. An unprepared digital entrepreneur may not honor his orders, and thus lose his clients.

\subsection{Digital Workplace}

Managingyourbusiness onlineallows digital entrepreneurs to take advantage of their presence on the web. This ICT development now offers digital entrepreneurs also the opportunity to have employees of different nationalities who can work on the same digital platform without being physically present in the workplace ${ }^{6}$.

\subsection{Digital Product}

Today, the Internet represents a space where hundreds are interconnected to give access to the global data available on hosts. Thus, it offers considerable potential for the distribution of digital products worldwide ${ }^{11}$. From an entrepreneurial point of view, commercializing a digital product offers several advantages that go beyond manufacturing, distribution or storage; On the digital side, the product can easily undergo significant changes without affecting the marketing process of the product.

\subsection{Digital Service}

Most start-ups that emerge in the digital domain offer exclusively a digital service. The latter represents for the client a huge profit because of the multitude of benefits that it includes: minimum cost of service and value perceived by the high customer ${ }^{6}$.In addition, the entrepreneur must ensure that the service provided is really worth the price charged, hence the need to move towards the market. It is essential for the digital entrepreneur to identify the desires of his customers and know what the competition is doing in order to meet their needs and always be ahead.To this end, digital entrepreneurs who build their business models exclusively on the digital presence, otherwise called «extreme entrepreneurs», unlike traditional or mild entrepreneurs, must always be attentive to their customers who are present only on a web space to contract a digital service ${ }^{6}$. 


\section{Typology of Digital Entrepreneurship}

Digital entrepreneurship can be divided into three types: the mild, the moderate and the extreme. The first type is the form of digital entrepreneurship where the use of digital channels is only à complement to traditional sales channels. Then, in the moderate digital entrepreneurship, the entrepreneur gives more importance to the web components and integrate them into his project. Finally, the extreme form of digital entrepreneurship is about to launch a completely digital company.importance to the web components and integrate them into his project. Finally, the extreme form of digital entrepreneurship is about to launch a completely digital company. Figure 1 show the typology of digital entrepreneurship ${ }^{6}$.

\begin{tabular}{|c|c|c|c|}
\hline \multirow[b]{2}{*}{ Artivily } & \multicolumn{3}{|c|}{ Categary of diffihal entrequencurntip } \\
\hline & Mild & Modenule & Ditran \\
\hline Marketing & Website as aupplement & $\begin{array}{l}\text { Digital marketieg is } \\
\text { primary mode }\end{array}$ & $\begin{array}{l}\text { Digital marketiang is } \\
\text { only mode }\end{array}$ \\
\hline Sales & $\begin{array}{l}\text { Product may be } \\
\text { available for sale } \\
\text { digitally }\end{array}$ & $\begin{array}{l}\text { Product can be } \\
\text { puichased digitally, } \\
\text { possibly exclusively }\end{array}$ & $\begin{array}{l}\text { Probact is only } \\
\text { avialukte for ale } \\
\text { digitally }\end{array}$ \\
\hline $\begin{array}{l}\text { Prodact } \\
\text { (good ar senice) }\end{array}$ & Muduct is ace digital & $\begin{array}{l}\text { Product may or may } \\
\text { not be digital }\end{array}$ & Prodact is digital \\
\hline Diatritution & $\begin{array}{l}\text { Modtuct is delivered by } \\
\text { physical means }\end{array}$ & $\begin{array}{l}\text { Product may te } \\
\text { detivered physically or } \\
\text { digitally }\end{array}$ & $\begin{array}{l}\text { Product is delivered } \\
\text { digieally }\end{array}$ \\
\hline $\begin{array}{l}\text { Stakchodder } \\
\text { management }\end{array}$ & $\begin{array}{l}\text { Traditional interactions, } \\
\text { eny inchuse e-mail }\end{array}$ & $\begin{array}{l}\text { Siguificant levels of } \\
\text { digizal interactions } \\
\text { traditional interactions } \\
\text { also common }\end{array}$ & $\begin{array}{l}\text { Dipital interactioes ane } \\
\text { pritury, trafitional } \\
\text { interations seldam } \alpha \\
\text { aever ocer }\end{array}$ \\
\hline Operzicans & 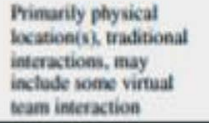 & $\begin{array}{l}\text { Phimanily physical } \\
\text { location(0), traditional } \\
\text { interactions, probubly } \\
\text { includes some virtual } \\
\text { weam inferaction }\end{array}$ & 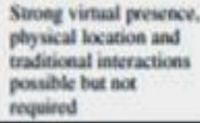 \\
\hline
\end{tabular}

Figure 1. Typology of digital entrepreneurship ${ }^{6}$.

\section{Methodology}

As part of this work, we will opt for a constructivist approach to build while being associated with digital entrepreneurs knowledge about the different typologies of digital entrepreneurship in Morocco. The approach associated with this posture is the qualitative approach. A field study was conducted among 06 digital entrepreneurs in Morocco. Starting from the fact that this is an exploratory study, we have chosen to carry out a qualitative study by opting for the method of semi-directive interviews, which consists in situating the respondent in a concrete experience through the schema. The proposed question and the order in which the questions are asked, this is why we have drawn up a list of topics to be addressed as the interview progresses in order to guide the respondent. It is:

- Presentation of the digital entrepreneur;

- The activity of the Moroccan digital entrepreneur; and

- The typology of the Moroccan digital entrepreneur.

Understanding in depth the typology of digital entrepreneurship in Morocco is in other words discover the motivations, opinions, attitudes and feelings underlying digital entrepreneurs. This is the objective of the semi-directive interview conducted.So, we chose as a measurement technique during our semi-directive interview, the LADDERING technique, which consists of starting with questions about the characteristics of the digital entrepreneur in Morocco, gradually moving to questions that reveal his hidden motives. The measurement technique chosen for semi-structured interviews is the horizontal and vertical analysis technique and summarize the results as a whole. For this study, we interviewed 06 Moroccan digital entrepreneurs. The choice of the sample size was based on the saturation principle, that is to say, we stopped the interrogation of new digital entrepreneurs when we noticed the redundancy of the answers. The people interviewed for this study were chosen according to the «snowball» method, asking each digital entrepreneur to recommend a colleague who could answer us.

\section{Result of the Study}

\subsection{Horizontal Analysis}

Theme 1.1: The age of digital entrepreneurs surveyed in this study varies between 25 and 37 years. This explains that digital entrepreneurship is rather young discipline.

Theme 1.2: Digital entrepreneurs have an advanced training diplomas from Moroccan high schools or universities in biology, management or economics. Also, they didn't all have the experience of working in an organization before embarking on entrepreneurship.

Theme 2.1: The digital entrepreneurs surveyed operate in different fields of activity. Each of them chose their activity 
Table 1. Analysis grid of conducted interviews

\begin{tabular}{|c|c|c|c|}
\hline & Interview 1 & Interview 2 & Interview 3 \\
\hline $\begin{array}{l}\text { Theme 1.1: Age of the } \\
\text { Digital Entrepreneur }\end{array}$ & 27 years & 32 years & 35 years \\
\hline $\begin{array}{l}\text { Theme 1.2: Academic and } \\
\text { professional career of the } \\
\text { digital entrepreneur }\end{array}$ & $\begin{array}{l}-\mathrm{Bac}+5 \text { in Marketing and sales } \\
\text { - No professional experiene }\end{array}$ & $\begin{array}{l}\text { - Bac }+5 \text { in international trade } \\
\text { - Experience of more than } 10 \\
\text { years in international shipping }\end{array}$ & $\begin{array}{l}- \text { Bac }+5 \text { in biology } \\
\text { - Experience of more than } 10 \\
\text { years }\end{array}$ \\
\hline $\begin{array}{l}\text { Theme 2.1: Field of activity } \\
\text { of the digital entrepreneur }\end{array}$ & $\begin{array}{l}\text { Sale of computer equipment and } \\
\text { accessories }\end{array}$ & $\begin{array}{l}\text { The sale of computer gadgets } \\
\text { and goodies }\end{array}$ & $\begin{array}{l}\text { The sale of organic and natural } \\
\text { products }\end{array}$ \\
\hline \multirow[t]{2}{*}{$\begin{array}{l}\text { Theme 2.2: Target and } \\
\text { project positioning }\end{array}$} & $\begin{array}{l}\text { Target: Any one wishing to } \\
\text { purchase computer hardware or } \\
\text { accessories }\end{array}$ & $\begin{array}{l}\text { Target: Anyone wishing to buy } \\
\text { computer goodies or gadgets }\end{array}$ & $\begin{array}{l}\text { Target: Anyone interested in } \\
\text { organic and natural products }\end{array}$ \\
\hline & $\begin{array}{l}\text { Positioning: This is an select } \\
\text { store where the person can find } \\
\text { all brands that offer computer } \\
\text { hardware }\end{array}$ & $\begin{array}{l}\text { Positioning : Put at the } \\
\text { disposal of Moroccans online } \\
\text { gadgets and computer goodies }\end{array}$ & $\begin{array}{l}\text { Positioning: Allow customers } \\
\text { direct online access to organic } \\
\text { and natural references }\end{array}$ \\
\hline $\begin{array}{l}\text { Theme 2.3: Products / } \\
\text { Services of the company }\end{array}$ & $\begin{array}{l}\text { Computer Hardware and } \\
\text { Accessories }\end{array}$ & Gadgets and computer goodies & Organic and natural products \\
\hline $\begin{array}{l}\text { Theme 3.1: The typology of } \\
\text { the digital project }\end{array}$ & $\begin{array}{l}\text { Moderate (e-commerce site + } \\
\text { physical stores) }\end{array}$ & Extreme (online site) & Extreme (online site) \\
\hline $\begin{array}{l}\text { Theme 3.2: The reasons for } \\
\text { choosing this positioning }\end{array}$ & $\begin{array}{l}\text { enjoy the benefits of the online } \\
\text { and physical store }\end{array}$ & $\begin{array}{l}\text { Strategic choice to reach a } \\
\text { target } 100 \% \text { connected and } \\
\text { who inevitably uses our } \\
\text { gadgets and goodies }\end{array}$ & $\begin{array}{l}\text { Make available to customers } \\
\text { the majority of organic and } \\
\text { natural references so that they } \\
\text { have direct access where they } \\
\text { are }\end{array}$ \\
\hline $\begin{array}{l}\text { Theme 3.3: The advantages } \\
\text { of this positioning }\end{array}$ & $\begin{array}{l}\text { Reaching a huge target with ease } \\
\text { of entry into the digital market }\end{array}$ & $\begin{array}{l}\text { Ease of entry into the market } \\
\text { and ease of distribution }\end{array}$ & $\begin{array}{l}\text { Ease of entry into the market } \\
\text { and ease of distribution }\end{array}$ \\
\hline $\begin{array}{l}\text { Theme 1.1: Age of the } \\
\text { Digital Entrepreneur }\end{array}$ & 28 years & 25 years & 37 years \\
\hline $\begin{array}{l}\text { Theme 1.2: Academic and } \\
\text { professional career of the } \\
\text { digital entre-preneur }\end{array}$ & $\begin{array}{l}- \text { Bac }+5 \text { in Logistics } \\
\text { - Experience of more than } 7 \\
\text { years as a supply chain manager }\end{array}$ & $\begin{array}{l}\text { - Bac }+5 \text { in Marketing and } \\
\text { sales } \\
\text { - Without experience }\end{array}$ & $\begin{array}{l}- \text { Bac }+5 \text { in finance } \\
\text { - More than } 10 \text { years } \\
\text { experience }\end{array}$ \\
\hline $\begin{array}{l}\text { Theme 2.1: Field of activity } \\
\text { of the digital entrepreneur }\end{array}$ & Home delivery of the races & Beauty products & $\begin{array}{l}\text { Home delivery of fruits and } \\
\text { vegetables of the season }\end{array}$ \\
\hline $\begin{array}{l}\text { Theme 2.2: Target and } \\
\text { project positioning }\end{array}$ & $\begin{array}{l}\text { Target: Moroccans wishing to be } \\
\text { delivered at any time of the day } \\
\text { Positioning: Providing } \\
\text { moroccans with a home delivery } \\
\text { service that will make their lives } \\
\text { easier }\end{array}$ & $\begin{array}{l}\text { Target: Women interested in } \\
\text { beauty and care products } \\
\text { Positioning: Making available } \\
\text { to women the majority of } \\
\text { international brands not } \\
\text { available in Morocco }\end{array}$ & $\begin{array}{l}\text { Target: Moroccans wishing to } \\
\text { be delivered fruits or vegetables } \\
\text { of the season at any time of the } \\
\text { day } \\
\text { Positioning: Providing } \\
\text { Moroccans with a home } \\
\text { delivery service that will make } \\
\text { their lives easier }\end{array}$ \\
\hline
\end{tabular}




\begin{tabular}{|l|l|l|l|}
\hline $\begin{array}{l}\text { Theme 2.3: Products / } \\
\text { Services of the company }\end{array}$ & Home delivery of the races & Beauty and care products & $\begin{array}{l}\text { Home delivery of fruits and } \\
\text { vegetables of the season }\end{array}$ \\
\hline $\begin{array}{l}\text { Theme 3.1: The typology of } \\
\text { the digital project }\end{array}$ & $\begin{array}{l}\text { Extreme (Website \& web } \\
\text { application) }\end{array}$ & $\begin{array}{l}\text { Moderate (e-commerce site \& } \\
\text { physical store) }\end{array}$ & Extreme (online site) \\
\hline $\begin{array}{l}\text { Theme 3.2: The reasons for } \\
\text { choosing this positioning }\end{array}$ & $\begin{array}{l}\text { Facilitate the life of Moroccans } \\
\text { through an online presence }\end{array}$ & $\begin{array}{l}\text { Moderate (e-commerce site } \\
\text { \&physical store) }\end{array}$ & $\begin{array}{l}\text { Facilitate the life of Moroccans } \\
\text { through an online presence }\end{array}$ \\
\hline $\begin{array}{l}\text { Theme 3.3: The advantages } \\
\text { of this positioning }\end{array}$ & $\begin{array}{l}\text { The ease of entry into the } \\
\text { market and the lack of cost of } \\
\text { distribution and storage + the } \\
\text { ease of distribution }\end{array}$ & $\begin{array}{l}\text { Enjoy the benefits of the online } \\
\text { and physical store }\end{array}$ & $\begin{array}{l}\text { Ease of entry into the market } \\
\text { and ease of distribution }\end{array}$ \\
\hline
\end{tabular}

based on their previous professional experience or chose a new activity that represents in their eyes a challenge.

Theme 2.2: These digital entrepreneurs market products and services that target a well-defined target and rely on their competitive advantage to distinguish themselves.

Theme 2.3: The products and services marketed by these digital entrepreneurs are: Computer hardware and accessories, computer gadgets and goodies, home delivery of groceries, organic and natural products, beauty and care products, home delivery of fruits and vegetables of the season.

Theme 3.1: The «Extreme» form of digital entrepreneurship is the typology of digital entrepreneurship that has been repeated several times between entrepreneurs.

Theme 3.2: The digital entrepreneurs interviewed for this study justify their choice of digital entrepreneurship typology by the desire to reach a huge target and to get closer to them because they are already online.

Theme 3.3: Mostly, ease of entry is the main advantage of the digital entrepreneurship typology chosen by digital entrepreneurs as shown in Table 1.

\subsection{Vertical Analysis}

First interviewee: The first digital entrepreneur interviewed in this study is a laureate of a large school with a $\mathrm{Bac}+5$ degree, he has never had a professional experience in the job market and has chosen to embark on entrepreneurship right out of school by creating a «select store» concept where they offer the majority of brands of hardware and accessories in a physical store and on an online site. This decision to choose the form of «moderate» digital entrepreneurship is motivated by its desire to reach a huge target and take advantage of the two channels: traditional and digital.

Second interviewee: Our second digital entrepreneur has master's degree in international trade, and has worked for more than 10 years in international shipping in one of the e-commerce giants in China. He decided to launch his project in Morocco selling goodies and computer gadgets and chose an extreme positioning for the latté. The ease of entry into the market and ease of distribution are the main advantages that led him to choose this form of digital entrepreneurship.

Third interviewee: This digital entrepreneur has a $\mathrm{Bac}+5$ in biology, she chose to embark on digital entrepreneurship through an online site «extreme format» selling organic and natural products. His choice was motivated by her desire to bring her different organic and natural references to Moroccans where they are and facilitate contact between her business and the customer.

Fourth interviewee : With a Bac +5 in Logistics, he was able to work more than 7 years as supply chain manager. In order to be his own boss, our digital entrepreneur today has a start-up home delivery of online shopping as an extreme positioning, he was able to prevail on the market and took advantage of a market entry, ease of storage and ease of distribution.

Fifth interviewee: This entrepreneur has capitalized on her acquired knowledge during her academic career and launched her business of beauty and care products after having graduated. She chose 
a "moderate" form of digital entrepreneurship to reach a huge target and enjoy the benefits of both physical and traditional channels.

Sixth interviewee: After his $\mathrm{Bac}+5$ in finance, he launched his own online project "extreme form" of home delivery of fruits and vegetables of the season to take advantage of the lack of manufacturing and storage costs, the ease of market entry and ease of distribution.

\section{Conclusions}

The conclusion we can draw from this analysis is as follows: These entrepreneurs are mainly young people who have completed higher education, are all well trained and informed entrepreneurs with more or less significant professional experiences. The ease of entry into the market is the main advantage that motivates them to opt for digital entrepreneurship through the "extreme" form. The digital entrepreneurs surveyed for this study have chosen to undertake on digital, their positioning is based primarily on the marketing of products or services either on the digital channel exclusively or by combining the two traditional and digital channels to gain the trust of their targets and develop their client portfolios.So, we can conclude that the typology of digital entrepreneurship mostly present in this study is "the extreme". In addition, the motivations that attracted these entrepreneurs to digital entrepreneurship are mainly: the ease of entry into the market, the absence of manufacturing and storage costs and ease of distribution.

\section{References}

1. Walker $H$. The virtual organisation: A new organizational form? International Journal of Networking and Virtual Organisations. 2006; 3(1):25-41. https://doi.org/10.1504/ IJNVO.2006.008783.

2. Bharadwaj A, El Sawy OA, Pavlou PA, Venkatraman NV. Digital business strategy: Toward a next genera- tion of insights, MIS Quarterly. 2013; 37(2):471-82. https://doi.org/10.25300/MISQ/2013/37:2.3.

3. Digital Transformation of European Industry and Enterprises; A report of the Strategic Policy Forum on Digital Entrepreneurship. Date accessed: 25/03/2015. https://ec.europa.eu/growth/content/report-digital-transformation-european-industry-and-enterprises-0_en .

4. Markus M, Loebbecke C. Commoditized digital processes and business community platforms: new opportunities and challenges for digital business strategies, MIS Quarterly. 2013; 37(2):649-54.

5. Davidson E, Vaast E. Digital Entrepreneurship and its Sociomaterial Enactment. Proceedings of 43rd Hawaii International Conference on Systeme Sciences, Hawaii, 2010. https://doi.org/10.1109/HICSS.2010.150.

6. Hull C, Hung YT, Hair N. Digital Entrepreneurship. EDGE; 2006.

7. Okkonen J. How virtual disorders affect knowledge work: Points on performance and knowledge management. International Journal of Networking and Virtual Organizations. 2004; 2(2):153-61. https://doi.org/10.1504/ IJNVO.2004.005136.

8. Hair N, Weitsch LR, Hull CE, Perott V, Hung Y. Market orientation in digital entrepreneurship: Advantages and challenges in a web 2.0 networked world, International Journal of Innovation and Technology Management. 2012; 9(6):18. https://doi.org/10.1142/S0219877012500459.

9. Hull CE, Caisy Hung YT, Hair N, Perotti V, Demartino R. Taking advantage of digital opportunities: A typology of digital entrepreneurship, International Journal of Networking and Virtual Organisations. 2007; 4(3):290-303. https://doi. org/10.1504/IJNVO.2007.015166.

10. Dy $M$, Carmina A. Unmasking the Internet: Investigating UK Women's Digital Entrepreneurship through Intersectionality. $\mathrm{PhD}$ thesis, University of Nottingham; 2015. p. 1-222.

11. Zahra S, Jennings A, Kuratko. The antecedents and consequences of firm-level entrepreneurship: The State of the field, Entrepreneurship Theory and Practice. 1999; 24(2):45-65. https://doi.org/10.1177/104225879902400205. 